\title{
Facile and efficient oxidation of sulfides to sulfoxides in water using hypervalent iodine reagents
}

\author{
Hirofumi Tohma, Tomohiro Maegawa, and Yasuyuki Kita*
}

Graduate School of Pharmaceutical Sciences, Osaka University, 1-6 Yamada-oka, Suita, Osaka, 565-0871, Japan

E-mail: kita@phs.osaka-u.ac.jp

Dedicated to Professor Anastasios Varvoglis on his $65^{\text {th }}$ birthday
(received 28 Jan 03; accepted 6 Mar 03; published on the web 16 Apr 03)

\begin{abstract}
Facile and efficient oxidation of sulfides to sulfoxides in water using iodosobenzene (PhIO) or phenyliodine diacetate (PIDA) was developed. Environmentally benign application using polymer-supported hypervalent iodine reagent, poly(diacetoxyiodo)styrene (PDAIS), in water is also described.
\end{abstract}

Keywords: Hypervalent iodine, sulfides, sulfoxides, environmentally benign reaction

\section{Introduction}

Hypervalent iodine reagents, which possess reactivity similar to that of heavy metal oxidants, have been used extensively in organic syntheses due to their low toxicity, ready availability and easy handling. ${ }^{1}$ Recently, economical and environmental concerns encourage the use of water as a reaction medium, and various aqueous oxidation reactions have been developed. ${ }^{2}$ Regarding hypervalent iodine(III) oxidation in water, only limited examples have been reported with reagents such as iodosobenzene and iodosobenzoic acid. ${ }^{3}$ Their practical utility and efficiency have been relatively low because they require long reaction times and vigorous reaction conditions for completion, yet, only give low to moderate yields in water (probably due to the generation of dihydroxyiodobenzene which has low reactivity). As a continuation of our studies on hypervalent iodine chemistry, ${ }^{4}$ we have studied the efficient activation of hypervalent iodine reagents in water using various additives under neutral reaction conditions. As a result, we developed efficient oxidation reactions of sulfides to sulfoxides in water using iodosobenzene (PhIO) or iodoxybenzene $\left(\mathrm{PhIO}_{2}\right)$ in the presence of a catalytic amount of the cationic surfactant, cetyltrimethylammonium bromide (CTAB). That is, water micelles formed by CTAB solubilized the substrate and the reagent, and remarkably enhanced the reaction rate (Eq. (1)). ${ }^{5}$ 


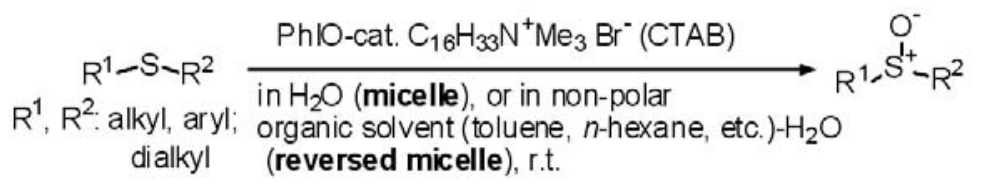

This methodology was extended to CTAB reversed micelle-mediated oxidation of sulfides in a variety of non-polar solvents such as toluene and $n$-hexane, which have not been used as the solvents in hypervalent iodine oxidation, in the presence of a small amount of water to afford the corresponding sulfoxides in excellent yields. Furthermore, we applied this reversed micellar system to catalytic asymmetric oxidation of sulfides to sulfoxides using $\mathrm{PhIO}_{2}$ in the presence of catalytic amounts of tartaric acid derivative and CTAB (Eq. (2)). ${ }^{6}$

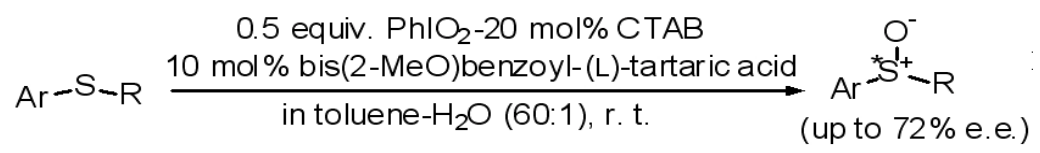

After various efforts to realize the highly enantioselective sulfoxidation in water, we found that inorganic bromide salts remarkably activate $\mathrm{PhIO}_{2}$ in water in the presence of catalytic amounts of dibenzoyl-(D)-tartaric acid to afford the corresponding sulfoxides with moderate enantioselectivities (Eq. (3)). ${ }^{7}$

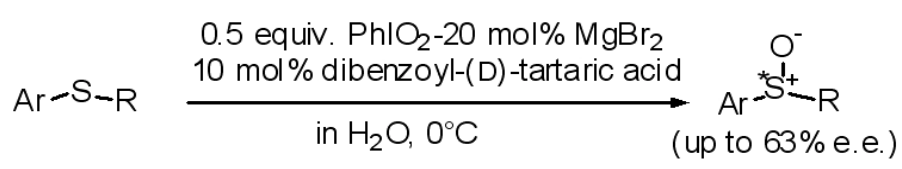

Next, to expand the utility of this facile activation of $\mathrm{PhIO}_{2}$ in water, we applied this system to the activation of iodine(III) reagents, which are commercialy available, more stable, and easier to handle (safer) than iodine(V) reagents. Consequently, we have recently achieved a facile and efficient oxidation of alcohols leading to the corresponding carboxylic acids, ketones, and lactones with $\mathrm{PhIO}$ and $\mathrm{KBr}$ in water under neutral conditions (Eq. (4)). ${ }^{8} \quad$ Furthermore, this bromide-mediated aqueous oxidation system was also found to be applicable to the activation of a recyclable polymer-supported hypervalent iodine(III) reagent, poly(diacetoxyiodo)styrene (PDAIS). Accordingly, we achieved an efficient and environmentally benign oxidation reaction of alcohols and diols leading to the corresponding ketones, carboxylic acids, and lactones in water (Eq. (4)). ${ }^{8}$ 


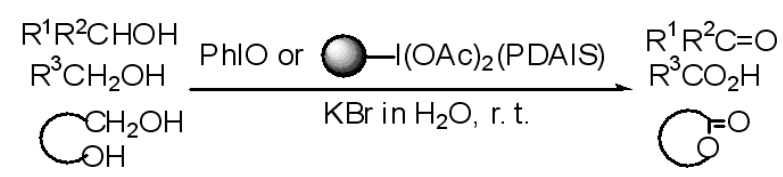

Herein, we report a facile and environmentally benign oxidation of sulfides to sulfoxides using safe and readily available iodine(III) reagents such as PhIO, phenyliodine diacetate (PIDA) and PDAIS with $\mathrm{KBr}$ in water.

\section{Results and Discussion}

To date the synthesis of sulfoxides from sulfides has been widely explored and numerous oxidants have been developed in an effort to achieve a facile, efficient, cheap and selective method. ${ }^{9}$ However, most reagents call for carefully controlled reaction conditions including the quantity of oxidants because of the formation of sulfones as side products. In particular, controlling the oxidation of diaryl sulfides to avoid formation of sulfones has been difficult since the first oxidation to the sulfoxides requires relatively high energy. ${ }^{10}$ On the other hand, several reports have shown that hypervalent iodine(III) oxidation using $\mathrm{PhIO},{ }^{11} \mathrm{PhI}(\mathrm{OCOR})_{2},{ }^{12}{ }^{1-}$ hydroxy-1,2-benziodoxol-3(1H)-one, ${ }^{13} \mathrm{PhI}(\mathrm{OTs}) \mathrm{OH},{ }^{14} \mathrm{PhICl}_{2},{ }^{15} \mathrm{PhIO}$-metalloporphyrin (or $\mathrm{Mn}(\mathrm{III})$-salen complex), ${ }^{16} \mathrm{PhIO}^{\mathrm{PhSeO}}{ }_{2} \mathrm{H},{ }^{17}$ PhIO-clay, ${ }^{18}$ (tert-butylperoxy)-iodanes, ${ }^{19}$ or PDAIS $^{20}$ is effective for the selective oxidation of sulfides to sulfoxides, yet, reagent insolubility and/or reactivity with several solvents limit the choice of solvents (preferably, acetonitrile, $\mathrm{CH}_{2} \mathrm{Cl}_{2}$ or $\mathrm{CHCl}_{3}$ ). Among the iodine(III) reagents, the use of recyclable PDAIS in halogenated solvents is a facile approach to sulfoxides. However, the corresponding sulfones were sometimes obtained as the major product in the oxidation of diarylsulfides using PDAIS in $\mathrm{CHCl}_{3}$. Furthermore, Varma and co-workers developed a solventless oxidation of sulfides using alumina-supported PIDA under microwave irradiation. ${ }^{21}$ This provides an environmentally benign method, but, seems to be difficult to scale up. On the other hand, we have already developed an efficient micelle-mediated sulfoxidation in water. ${ }^{5}$ However, this method still has a drawback, that is, excess amount of organic solvent for work-up is needed due to the enhanced solubility of both the reagents and product in water. Thus, we investigated a more practical and more environmentally friendly sulfoxidation in water using hypervalent iodine(III) reagents than previously reported iodine(III)-induced reactions.

We first examined the oxidation of various sulfides (1) including alkylaryl sulfide, dialkyl sulfide, and diaryl sulfides with the combined reagent, $\mathrm{PhIO}-\mathrm{KBr}$, which we previouslly developed for the oxidation of alcohols, in water. These results are summarized in Table 1. Table 1 shows that both 1.5 equiv. of $\mathrm{PhIO}$ and a stoichiometric amount of $\mathrm{KBr}$ are necessary to complete the oxidation of the less reactive diphenyl sulfide 1c compared to alkylaryl- or dialkyl sulfides (entries 1-4). No sulfone was obtained from this reaction. Furthermore, this reaction was 
not applicable for the synthesis of diaryl sulfoxides (1e, f) having an electron-withdrawing group (entries 6, 7).

Therefore, we re-examined the reaction conditions including the use of other iodine(III) reagents to improve the generality of this reaction. As a result, the use of PIDA, which is more reactive than $\mathrm{PhIO}$, improved the generality, shortened the reaction time, and reduced the amount of $\mathrm{KBr}$ to yield the corresponding sulfoxides (2) in good yields, while only a small amount of sulfones were also obtained as the by-product in some cases (entries 1, 4, 5). The results are shown in Table 2.

Table 1. Oxidation of sulfides $\left(\mathrm{R}^{1}-\mathrm{S}-\mathrm{R}^{2}\right)(\mathbf{1 a - f})$ to sulfoxides $\left(\mathrm{R}^{1}-\mathrm{S}(\mathrm{O})-\mathrm{R}^{2}\right)(\mathbf{2 a - f})$ using PhIO (1.5 equiv.)-KBr (1.0 equiv.) in water (0.2 M)

\begin{tabular}{|c|c|c|c|c|}
\hline \multirow[t]{2}{*}{ Entry } & \multicolumn{2}{|c|}{ Substrate $\left(\mathrm{R}^{1}-\underline{\mathrm{S}}^{-\mathrm{R}^{2}} \underline{\mathbf{( 1 )}}\right.$} & \multirow[t]{2}{*}{ Time (h) } & \multirow[t]{2}{*}{ Yield $^{\mathrm{a}}(\%)$} \\
\hline & $\mathrm{R}^{1}$ & $\mathrm{R}^{2}$ & & \\
\hline $1^{\mathrm{b}}$ & 4- $\mathrm{MeC}_{6} \mathrm{H}_{4}$ & Me (1a) & 3 & quant. \\
\hline $2^{b}$ & $\mathrm{PhCH}_{2}$ & Me (1b) & 3 & 95 \\
\hline $3^{b}$ & $\mathrm{Ph}$ & $\mathrm{Ph}(\mathbf{1 c})$ & 24 & 64 (quant. $^{\mathrm{c}}$ ) \\
\hline 4 & $\mathrm{Ph}$ & Ph (1c) & 24 & quant. \\
\hline 5 & 4- $\mathrm{MeC}_{6} \mathrm{H}_{4}$ & $\mathrm{Ph}$ (1d) & 4 & 94 \\
\hline 6 & $4-(\mathrm{CN}) \mathrm{C}_{6} \mathrm{H}_{4}$ & $\mathrm{Ph}$ (1e) & 24 & 25 \\
\hline 7 & 4- $\left(\mathrm{NO}_{2}\right) \mathrm{C}_{6} \mathrm{H}_{4}$ & $\mathrm{Ph}$ (1f) & 24 & trace \\
\hline
\end{tabular}

a Isolated yields. ${ }^{\mathrm{b}} 1.1$ equiv. PhIO and 0.1 equiv. KBr were used. ${ }^{\mathrm{c}}$ Yield based on the reacted substrate.

Table 2. Oxidation of sulfides 1 to sulfoxides 2 using PIDA (1.1 equiv.)-KBr (0.1 equiv.) in water $(0.2 \mathrm{M})$

\begin{tabular}{cccc}
\hline Entry & Substrate (1) & Time (h) & Yield $^{\mathrm{a}}(\%)$ \\
\hline 1 & 1a & 0.5 & $82^{\mathrm{c}}$ \\
2 & 1b & 0.5 & 85 \\
3 & $\mathbf{1 c}$ & 5 & 96 \\
$4^{\mathrm{b}}$ & $\mathbf{1 e}$ & 1 & $85^{\mathrm{d}}$ \\
$5^{\mathrm{b}}$ & 1f & 1 & $83^{\mathrm{d}}$ \\
\hline
\end{tabular}

${ }^{\mathrm{a}}$ Isolated yields. ${ }^{\mathrm{b}} 1.5$ equiv. PIDA was used. ${ }^{\mathrm{c}} 6 \%$ of sulfone was also obtained. ${ }^{\mathrm{d}}$ Only a trace amount of sulfone was also obtained.

Thus, we achieved a general and efficient oxidation of sulfides to sulfoxides in water using PhIO or PIDA.

Next, we applied the above mentioned reactions to a facile and environmentally benign reaction using a polymer-supported hypervalent iodine(III) reagent. Polymer-supported 
hypervalent iodine reagents are expected to be useful for pharmaceutical and agrochemical industries due to their versatility, low toxicity and high yields. ${ }^{22}$ Recently, Togo et al., ${ }^{20 a, 23}$ Ley et al., ${ }^{24}$ and $\mathrm{we}^{8,25}$ demonstrated that poly (diacetoxyiodo)styrene (PDAIS) ${ }^{26}$ and poly bis(trifluoroacetoxyiodo)styrene (PBTIS) show similar reactivities to diacyloxyiodobenzenes and utilized them as a replacement for previously reported iodine(III) reagents. In addition, after the reactions, the resin (poly 4-iodostyrene) is readily recoverable and recyclable. Therefore, we investigated the use of recyclable PDAIS for the oxidation of sulfides in water. As a result, the corresponding sulfoxides were obtained exclusively in good to excellent yields without forming sulfones when using PDAIS, while longer reaction time was needed for reaction completion than when using PIDA (Table 3).

Table 3. Oxidation of sulfides 1 to sulfoxides 2 using PDAIS (1.1-1.5 equiv.)-KBr (0.2 equiv.) in water $(0.2 \mathrm{M})$

\begin{tabular}{cccc}
\hline Entry & Substrate (1) & Time $(\mathrm{h})$ & Yield $^{\mathrm{a}}(\%)$ \\
\hline 1 & $\mathbf{1 a}$ & 9 & quant. \\
2 & $\mathbf{1 b}$ & 6 & 92 \\
3 & $\mathbf{1 c}$ & 15 & 90 \\
4 & $\mathbf{1 d}$ & 3 & 94 \\
$5^{\mathrm{b}}$ & $\mathbf{1 e}$ & 24 & 94 \\
$6^{\mathrm{b}}$ & $\mathbf{1 f}$ & 24 & $55\left(91^{\mathrm{c}}\right)$ \\
\hline
\end{tabular}

${ }^{\mathrm{a}}$ Isolated yields. ${ }^{\mathrm{b}} 1.5$ equiv. PDAIS was used. ${ }^{\mathrm{c}}$ Yield based on the reacted substrate.

The procedure of this reaction using PDAIS is simple, facilitates the recycling of the reagent and reduces the necessary amount of organic solvents to a minimum level, since all the work-up is carried out by filtration. Of course, the recovered iodinated resin can be regenerated and recycled successfully.

\section{Conclusions}

We achieved a facile and efficient oxidation of sulfides to sulfoxides in water using hypervalent iodine(III) reagents in the presence of $\mathrm{KBr}$. The environmentally benign procedure described herein will provide a new practical method for sulfoxidation in water because of its simple operation, use of the non-toxic and recyclable reagent, reduction of environmental wastes, and the inhibition of overoxidation to sulfones.

\section{Experimental Section}


General Procedures. All melting points are uncorrected. Infrared (IR) absorption spectra $\left(\mathrm{cm}^{-1}\right)$ were recorded on a SHIMADZU FTIR-8400 instrument. ${ }^{1} \mathrm{H}-\mathrm{NMR}$ (and ${ }^{13} \mathrm{C}-\mathrm{NMR}$ ) spectra were recorded on a JEOL JNM-EX 300 and JEOL JNM-EX 270 with TMS as an internal standard. Merck silica gel 60 was used for column chromatography, and E. Merck pre-coated TLC plates and silica gel $\mathrm{F}_{254}$ were used for preparative thin-layer chromatography. PhIO was purchased from Tokyo Chemical Industry Co., Ltd. (TCI). PIDA was purchased from Aldrich. Other commercially available compounds 1a-c, 1f, and $\mathrm{KBr}$ were purchased from Aldrich, Acros and TCI, and were used without further purification. Compounds 1d, e were prepared according to the known procedure. ${ }^{27}$ The known products $2 \mathbf{a}-\mathbf{d}$ and $\mathbf{2 f}$ were characterized by comparing their spectral and physical data with the literature values. ${ }^{28-32}$ Poly(diacetoxyiodo)styrene, PDAIS, was prepared by known procedures. ${ }^{26}$ The filter (abselut ${ }^{\mathrm{TM}}$ NEXUS ) for work-up was commercially available from Varian.

Phenyl 4-tolyl sulfide (1d). ${ }^{28}$ yellow oil; IR (KBr) $\mathrm{cm}^{-1}$ : 2924, 1584, 1493, 1478, 1439, 1262 , 1084, 808, 741. ${ }^{1} \mathrm{H}$ NMR $\left(\mathrm{CDCl}_{3}\right)$ \&: 2.27 (3H, s), 7.05-7.24 (9H, m). MS m/z $200\left(\mathrm{M}^{+}\right.$), 184, 91. 4-Cyanophenyl phenyl sulfide (1e). ${ }^{29}$ colorless oil; IR $(\mathrm{KBr}) \mathrm{cm}^{-1}$ : 2924, 2226, 1593, 1439 ,

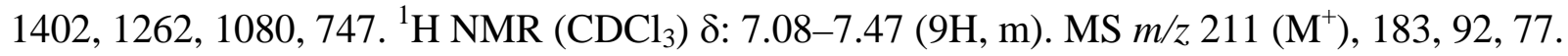

\section{General procedure for the oxidation of sulfides to sulfoxides using PhIO-KBr in water}

To a stirred suspension of $1(0.20 \mathrm{mmol})$ and $\mathrm{KBr}(0.20 \mathrm{mmol})$ in $\mathrm{H}_{2} \mathrm{O}(1.0 \mathrm{~mL})$, PhIO (0.30 mmol) was added at room temperature, and the mixture was stirred for several hours. After completion of the reaction, AcOEt was added to the reaction mixture. The mixture was extracted with AcOEt , dried, and evaporated. The residue was purified by column chromatography $\left(\mathrm{SiO}_{2} /\right.$ AcOEt-n-hexane) to give pure 2 .

\section{General procedure for the oxidation of sulfides to sulfoxides using PIDA-KBr in water}

To a stirred suspension of $1(0.20 \mathrm{mmol})$ and $\mathrm{KBr}(0.02 \mathrm{mmol})$ in $\mathrm{H}_{2} \mathrm{O}(1.0 \mathrm{~mL})$, PIDA (0.22 mmol) was added at room temperature, and the mixture was stirred for several hours. After completion of the reaction, AcOEt was added to the reaction mixture. The mixture was extracted with AcOEt , dried, and evaporated. The residue was purified by column chromatography $\left(\mathrm{SiO}_{2} /\right.$ AcOEt-n-hexane) to give pure 2.

\section{General procedure for the oxidation of sulfides to sulfoxides using PDAIS-KBr in water}

To a stirred suspension of $\mathbf{1}(1.0 \mathrm{mmol})$ and $\mathrm{KBr}(0.2 \mathrm{mmol})$ in $\mathrm{H}_{2} \mathrm{O}$ (5.0 mL), PDAIS (1.1 mmol) was added at room temperature and stirred for several hours. After completion of the reaction, the reaction mixture was filtered through abselut ${ }^{\mathrm{TM}}$ NEXUS (Varian) and washed with a small amount of water to remove $\mathrm{KBr}$. The residue was extracted with $\mathrm{MeOH}$, and the filtrate was evaporated. The residue was purified by column chromatography ( $\mathrm{SiO}_{2} / \mathrm{AcOEt}-n$-hexane) to give pure 2 . 
Methyl 4-tolyl sulfoxide (2a). colorless crystal; mp 44-46 ${ }^{\circ} \mathrm{C}\left(\mathrm{Et}_{2} \mathrm{O}\right)$ (commercially available from Aldrich; mp 44-46 $\left.{ }^{\circ} \mathrm{C}\right)$. IR (KBr) cm ${ }^{-1}$ : 3010, 1590, 1495, 1088, 1043. ${ }^{1} \mathrm{H} \mathrm{NMR}\left(\mathrm{CDCl}_{3}\right) \delta$ : 2.42 (3H, s), 2.71 (3H, s), $7.33(2 \mathrm{H}, \mathrm{d}, J=8.1 \mathrm{~Hz}), 7.54(2 \mathrm{H}, \mathrm{d}, J=8.1 \mathrm{~Hz}) .{ }^{13} \mathrm{C}$ NMR $\left(\mathrm{CDCl}_{3}\right) \delta$ : 21.4, 44.0, 123.4, 129.9, 141.3, 142.3. MS m/z $154\left(\mathrm{M}^{+}\right)$, 58.

Benzyl methyl sulfoxide (2b). colorless crystal; mp $51{ }^{\circ} \mathrm{C}\left(\mathrm{Et}_{2} \mathrm{O}\right)$ ( $\mathrm{Lit}^{30} \mathrm{mp} 54{ }^{\circ} \mathrm{C}$ ). IR $(\mathrm{KBr}) \mathrm{cm}^{-1}:$ 3032, 1496, 1456, 1074, 1047, 767. ${ }^{1} \mathrm{H} \mathrm{NMR}\left(\mathrm{CDCl}_{3}\right) \delta: 2.45(3 \mathrm{H}, \mathrm{s}), 3.93(1 \mathrm{H}$, ABq, $J=12.8 \mathrm{~Hz}), 4.06(1 \mathrm{H}, \mathrm{ABq}, J=12.8 \mathrm{~Hz}), 7.21-7.45(5 \mathrm{H}, \mathrm{m}) .{ }^{13} \mathrm{C} \mathrm{NMR}\left(\mathrm{CDCl}_{3}\right) \delta: 37.3$, 60.3, 128.4, 128.9, 129.6, 129.9. MS m/z $154\left(\mathrm{M}^{+}\right), 92$.

Diphenyl sulfoxide (2c). colorless crystal; mp 70-72 ${ }^{\circ} \mathrm{C}\left(\mathrm{Et}_{2} \mathrm{O}\right)$ (commercially available form Aldrich. mp 69-71 $\left.{ }^{\circ} \mathrm{C}\right)$. IR (KBr) cm ${ }^{-1}$ : 3058, 1476, 1445, 1092, 1046, 743. ${ }^{1} \mathrm{H} \mathrm{NMR}\left(\mathrm{CDCl}_{3}\right) \delta$ : 7.43-7.66 (10H, m). ${ }^{13} \mathrm{C} \mathrm{NMR}\left(\mathrm{CDCl}_{3}\right) \delta: 124.7,129.3,131.0,145.6 . \mathrm{MS} \mathrm{m} / \mathrm{z} 202\left(\mathrm{M}^{+}\right), 185$, 154, 109, 97, 77, 65, 51.

Phenyl 4-tolyl sulfoxide (2d). colorless crystal; mp 66-69 ${ }^{\circ} \mathrm{C}\left(\mathrm{Et}_{2} \mathrm{O}\right)\left(\mathrm{Lit}^{31} \mathrm{mp} 78-82{ }^{\circ} \mathrm{C}\right)$. IR $(\mathrm{KBr}) \mathrm{cm}^{-1}:$ 1445, 1090, 1046, 1017, 749. ${ }^{1} \mathrm{H} \mathrm{NMR}\left(\mathrm{CDCl}_{3}\right) \delta: 2.27$ (3H, s), 7.17 (2H, d, $J=8.2$ $\mathrm{Hz}), 7.33-7.38$ (3H, m), 7.45 (2H, d, $J=8.2 \mathrm{~Hz}), 7.53-7.56(2 \mathrm{H}, \mathrm{m}) .{ }^{13} \mathrm{C} \mathrm{NMR}\left(\mathrm{CDCl}_{3}\right) \delta: 21.3$, 124.6, 124.9, 129.2, 129.9, 130.8, 141.5, 142.4, 145.7. MS m/z $216\left(\mathrm{M}^{+}\right), 168,123,107,79$.

4-Cyanophenyl phenyl sulfoxide (2e). colorless crystal; mp $70-72^{\circ} \mathrm{C}\left(\mathrm{Et}_{2} \mathrm{O}\right) . \mathrm{IR}(\mathrm{KBr}) \mathrm{cm}^{-1}$ : 2232, 1593, 1485, 1445, 1395, 1088, 1049, 1017, 999, 833. ${ }^{1} \mathrm{H}$ NMR $\left(\mathrm{CDCl}_{3}\right)$ 8: 7.41-7.44 (3H, m), 7.57-7.61 (2H, m), $7.68(4 \mathrm{H}, \mathrm{m},) .{ }^{13} \mathrm{C} \mathrm{NMR}\left(\mathrm{CDCl}_{3}\right) \delta: 114.6,117.7,124.8,125.0,129.7$, 131.9, 132.9, 144.5, 151.2. MS m/z $227\left(\mathrm{M}^{+}\right)$, 179, 109, 77. Anal. Calcd. for $\mathrm{C}_{13} \mathrm{H}_{9} \mathrm{NOS}$ : C, 68.70; H, 3.99; N, 6.16. Found: C, 68.62; H, 4.14; N, 6.13.

4-Nitrophenyl phenyl sulfoxide (2f). yellow crystal; mp $105-109{ }^{\circ} \mathrm{C}\left(\mathrm{Et}_{2} \mathrm{O}\right)\left(\mathrm{Lit}^{32} \mathrm{mp} 100-101\right.$ $\left.{ }^{\circ} \mathrm{C}\right)$. IR (KBr) $\mathrm{cm}^{-1}: 1524,1345,1049,852 .{ }^{1} \mathrm{H}$ NMR $\left(\mathrm{CDCl}_{3}\right)$ 8: 7.42-7.44 (3H, m), 7.59-7.63 $(2 \mathrm{H}, \mathrm{m}), 7.76$ (2H, d, $J=8.9 \mathrm{~Hz}), 8.24(2 \mathrm{H}, \mathrm{d}, J=8.9 \mathrm{~Hz}) .{ }^{13} \mathrm{C}$ NMR $\left(\mathrm{CDCl}_{3}\right) \delta: 124.4,124.9$, 125.2, 129.8, 132.0, 144.4 149.2, 152.9. MS m/z $247\left(\mathrm{M}^{+}\right), 109,77$.

\section{Acknowledgements}

This work was supported by Grant-in-Aid for Scientific Research (S) and for Encouragement of Young Scientists from the Ministry of Education, Science, Sports and Culture, Japan. HT also thanks Industrial Technology Research Grant Program from New Energy and Industrial Technology Development Organization (NEDO) of Japan.

\section{References}

1. Recent reviews see: (a) Stang, P. J.; Zhdankin, V. V. Chem. Rev. 1996, 96, 1123. (b) Kita, Y.; Takada, T.; Tohma, H. Pure Appl. Chem. 1996, 68, 627. (c) Varvoglis, A. Hypervalent Iodine in Organic Synthesis, Academic Press, San Diego, 1997. (d) Kitamura, T.; Fujiwara, 
Y. Org. Prep. Proc. Int. 1997, 29, 409. (e) Wirth, T.; Hirt, U. H. Synthesis 1999, 1271. (f) Zhdankin, V. V.; Stang, P. J. Chem. Rev. 2002, 102, 2523. (g) Moreno, I.; Tellitu, I.; Herrero, M. T.; SanMartín, R.; Domínguez, E. Curr. Org. Chem. 2002, 6, 1433. (h) Wirth, T. Ed. Hypervalent Iodine Chemistry, Spinger-Verlag, Berlin, Heidelberg, 2003.

2. (a) Li, C. J.; Chan, T. H. Eds. Organic Reactions in Aqueous Media; John Wiley: New York, 1997. (b) Grieco, P. A. Ed.; Organic Synthesis in Water, Blackie Academic: London, 1998. (c) Cornils, B.; Herrmann, W. A. Ed.; Aqueous-Phase Organometallic Catalysis, WileyVCH: Weinheim, 1998.

3. (a) Moriarty, R. M.; Vaid, R. K.; Duncan, M. P.; Ochiai, M.; Inenaga, M.; Nagao, Y. Tetrahedron Lett. 1988, 29, 6913. (b) Ochiai, M.; Inenaga, M.; Nagao, Y.; Moriarty, R. M.; Vaid, R. K.; Duncan, M. P. Tetrahedron Lett. 1988, 29, 6917. (c) Moriarty, R. M.; Prakash, O.; Duncan, M. P.; Vaid, R. K.; Rani, N. J. J. Chem. Res (S) 1996, 432.

4. For our recent work, see: (a) Kita, Y.; Tohma, H.; Hatanaka, K.; Takada, T.; Fujita, S.; Mitoh, S.; Sakurai, H.; Oka, S. J. Am. Chem. Soc. 1994, 116, 3684. (b) Kita, Y.; Arisawa, M.; Gyoten, M.; Nakajima, M.; Hamada, R.; Tohma, H.; Takada, T. J. Org. Chem. 1998, 63, 6625. (c) Kita, Y.; Egi, M.; Takada, T.; Tohma, H. Synthesis 1999, 885. (d) Arisawa, M.; Ramesh, N. G.; Nakajima, M.; Tohma, H.; Kita, Y. J. Org. Chem. 2001, 66, 59. (e) Hamamoto, H.; Anilkumar, G.; Tohma, H.; Kita, Y. Chem. Eur. J. 2002, 8, 5377. (f) Tohma, H.; Iwata, M.; Maegawa, T.; Kita, Y. Tetrahedron Lett. 2002, 43, 9241 and references cited therein.

5. Tohma, H.; Takizawa, S.; Watanabe, H.; Kita, Y. Tetrahedron Lett. 1998, 39, 4547.

6. Tohma, H.; Takizawa, S.; Watanabe, H.; Fukuoka, Y.; Maegawa, T.; Kita, Y. J. Org. Chem. 1999, 64, 3519.

7. Tohma, H.; Takizawa, S.; Morioka, H.; Maegawa, T.; Kita, Y. Chem. Pharm. Bull. 2000, 48, 445.

8. (a) Tohma, H.; Takizawa, S.; Maegawa, T.; Kita, Y. Angew. Chem., Int. Ed. 2000, 39, 1306.

(b) Tohma, H.; Maegawa, T.; Takizawa, S.; Kita, Y. Adv. Synth. Catal. 2002, 344, 328.

9. (a) Hudlicky, M. Oxidations in Organic Chemistry. Washington DC: ACS Monograph, 1990, p 252. (b) Mata, E. G. Phosphorus, Sulfur, and Silicon and the Related Elements 1996, 117, 231.

10. Oae, S. Ed.; Organic Chemistry of Sulfur. New York: Plenum Press, 1977; Chapter 8.

11. (a) Ford-Moore, A. H. J. Chem. Soc. 1949, 2126. (b) Takaya, T.; Enyo, H.; Imoto, E. Bull. Chem. Soc. Jpn. 1968, 41, 1032.

12. (a) Szmant, H. H.; Lapinski, R. L. J. Am. Chem. Soc. 1956, 78, 458. (b) Imamoto, T.; Koto, H. Chem. Lett. 1986, 967. (c) Ray, D. G., III; Koser, G. F. J. Org. Chem. 1992, 57, 1607. (c) Humffray, A. A.; Imberger, H. E. J. Chem. Soc., Perkin Trans. 2 1981, 382. (d) Srinivasan, C.; Chellamani, A.; Kuthalingam, P. J. Org. Chem. 1982, 47, 428.

13. Folsom, H. E.; Castrillon, J. Synth. Commun. 1992, 22, 1799. 
14. (a) Koser, G. F.; Kokil, P. B.; Shah, M. Tetrahedron Lett. 1987, 28, 5431. (b) Miyata, O.; Nishiguchi, A. Ninomiya, I.; Naito, T. Chem. Pharm. Bull. 1996, 44, 1285. (c) Min, X.; Chen, Z. C. Synth. Commun. 1997, 27, 1315.

15. Barbieri, G.; Cinquini, M.; Colonna, S.; Montanari, F. J. Chem. Soc. C 1968, 659.

16. (a) Ando, W.; Tajima, R.; Takata, T. Tetrahedron Lett. 1982, 23, 1685. (b) Pautet, F.; Daudon, M. Tetrahedron Lett. 1991, 32, 1457. (c) Noda, K.; Hosoya, N.; Yanai, K.; Irie, R.; Katsuki, T. Tetrahedron Lett. 1994, 35, 1887.

17. Roh, K. R.; Kim, K. S.; Kim, Y. H. Tetrahedron Lett. 1991, 32, 793.

18. Kannan, P.; Sevvel, R.; Rajagopal, S.; Pitchumani, K.; Srinivasan, C. Tetrahedron 1997, 53, 7635.

19. Ochiai, M.; Nakanishi, A.; Ito, T. J. Org. Chem. 1997, 62, 4253.

20. (a) Togo, H.; Abe, S.; Nogami, G.; Yokoyama, M. Bull. Chem. Soc. Jpn. 1999, 72, 2351. (b) Wang, G. P.; Chen, Z. C. Synth. Commun. 1999, 29, 2859.

21. Varma, R. S.; Saini, R. K.; Dahiya, R. J. Chem. Res. (S) 1998, 120.

22. Reviews see: (a) Drewry, D. H.; Coe, D. M.; Poon, S. Med. Res. Rev. 1999, 19, 97. (b) Ley, S. V.; Baxendale, I. R.; Bream, R. N.; Jackson, P. S.; Leach, A. G.; Longbottom, D. A.; Nesi, M.; Scott, J. S.; Storer, R. I.; Taylor, S. J. J. Chem. Soc., Perkin Trans. 1 2000, 3815. (c) Bhalay, G.; Dunstan, A.; Glen, A. Synlett 2000, 1846. (d) Kirschning, A.; Monenschein, H.; Wittenberg, R. Angew. Chem., Int. Ed. 2001, 40, 650. (e) Togo, H.; Sakuratani, K. Synlett 2002, 1966.

23. (a) Togo, H.; Nogami, G.; Yokoyama, M. Synlett 1998, 534. (b) Abe, S.; Sakuratani, K.; Togo, H. Synlett 2001, 22. (c) Abe, S.; Sakuratani, K.; Togo, H. J. Org. Chem. 2001, 66, 6174.

24. (a) Ley, S. V.; Thomas, A. W.; Finch, H. J. Chem. Soc., Perkin Trans 1 1999, 669. (b) Ley, S. V.; Schucht, O.; Thomas, A. W.; Murray, P. J. J. Chem. Soc., Perkin Trans. 1 1999, 1251. (c) Baxendale, I. R.; Ley, S. V.; Piutti, C. Angew. Chem., Int. Ed. 2002, 41, 2194. (d) Baxendale, I. R.; Lee, A.-L.; Ley, S. V. J. Chem. Soc., Perkin Trans. 1 2002, 1850.

25. (a) Tohma, H.; Morioka, H.; Takizawa, S.; Arisawa, M.; Kita, Y. Tetrahedron 2001, 57, 345. (b) Tohma, H.; Morioka, H.; Harayama, Y.; Hashizume, M.; Kita, Y. Tetrahedron Lett. 2001, 42, 6899.

26. (a) Okawara, M.; Mizuta, K. Kogyo Kagaku Zasshi 1961, 64, 232. (b) Yamada, Y.; Okawara, M. Makromol. Chem. 1972, 152, 153. (c) Hallensleben, M. L. Angew. Makromol. Chem. 1972, 27, 223.

27. Kuethe, J. T.; Cochran, J. E.; Padwa, A. J. Org. Chem. 1995, 60, 7082.

28. Chandrasekaran, R.; Perumal, S.; Wilson, D. A. Magn. Reson. Chem. 1987, 25, 1001.

29. Percec, V.; Bae, J-Y.; Hill, D. H. J. Org. Chem. 1995, 60, 6895.

30. Toutchkine, A.; Aebisher, D.; Clennan, E. L. J. Am. Chem. Soc. 2001, 123, 4966.

31. Ridley, D. D.; Small, M. A.; Aust. J. Chem. 1982, 35, 495.

32. Colonna, S.; Banfi, S.; Annunziata, R.; Casella, L. J. Org. Chem. 1986, 51, 891. 